\title{
Resistances to Autobiography: The Indian Experiment with life-writing
}

\author{
Sanghamitra Sadhu \\ PhD, Assistant Professor, Department of English, Cotton University, Guwahati, Assam \& Former \\ Fellow at Indian Institute of Advanced Study, Shimla. Email: sadhusanghamitra@gmail.com
}

\begin{abstract}
The article underlines that the epistemology of the self and the practice of life-writing in India marks a departure from the Western conventions and modes of expression. Although there are resistances to autobiography from the Western theoretical standpoint, the genre meets with a twofold resistance in postcolonial milieu in its negotiation with the Indian metaphysics of self. Autobiography in decolonising India negotiates complex pathways between an ardent adherence to Indian epistemology and a potent resistance to the Western modes of writing the self. In a framework to understand the phenomenon of resistance implicit in autobiography in general and the internal resistances to autobiography manifest in the genre during decolonisation in particular, the article argues that such resistances within the genre have redefined the very idea of the self in writing, generated a nuanced notion of the self in narration, as well as challenged the process of writing the self in decolonisation.
\end{abstract}

Keywords: autobiography, postcolonial life-writing, hybridity, decentering, decolonisation, India

\section{Introduction}

Autobiography as a canonical genre in the West with its celebration of the grand narrative of the sovereign self has come under severe critique in recent times. The concept of 'sovereign' self is no longer amenable to the discourse of life-writing which underlines autobiography's inability to incorporate the diverse life narratives in its corpus. The transition from auto/biography to lifewriting in the present time is germane to the philosophical debate between the transcendental and the empirical, as the question of ontology of the 'autos' or the self in autobiography is directed towards the empirical dimension of life enclosed in life-writing. In Greek 'autos' signifies 'self'; 'bios' 'life', and 'graphy' 'writing'. Combined together as 'self-life-writing', the expression points to the culmination of 'autobiography', where autobiography and life-writing occupy a synonymous semantic space. The French theorist Philippe Lejeune defines autobiography as "the retrospective narrative in prose that someone makes of his own existence when he puts the principal accent upon his life, especially upon the story of his own personality" (1989, p.4). In Lejeune's definition 'life' is a pointer to the how or becoming of a self at a particular point of self's reflection which autobiography as a term proves inadequate to address. Similarly, James Olney in 
discussing the writings of Augustine, Rousseau, and Beckett in Memory and Narrative expresses his disenchantment with the term autobiography and looks for a more inclusive term than autobiography:

Although I have in the past written frequently about autobiography as a literary genre, I have never been very comfortable doing it, primarily because I believe that if one is to speak relevantly of a genre one has first of all to define it, and I have never met a definition of autobiography that I could really like (1998, p. xv).

Olney makes an important distinction between the noun 'autobiography' and the adjective 'autobiographical' further implying the problematic that a work may be 'autobiographical' without being an 'autobiography' proper and vice versa. He also mentions the gradual alteration of 'evolution or devolution' in the nature of autobiography over the past sixteen centuries, the focus shifting from bios, the course of a life-time to autos -- the self-writing and the self being written. However, one might point to an internal shift within the process of writing the autos i.e. the shift from writing the ontology of the autos to writing about or around the self, reflecting the empirical dimensions of life. In contrast to using an inflexible term like autobiography, Olney's preference is for life-writing or periautobiography which means 'writing around or about the self'. For Olney such an expression hints at 'indefinition or the lack of generic rigour' which precisely conforms to the uncertainty involved in the process of writing about a highly variable category called 'self'.

\section{Autobiography: The Definitional Unease}

At the level of discourse autobiography begins and ends in a double-bind; any attempt to define it leads to de-defining of the genre and any analysis of its structure ends up in de-structuring. Writing on the fact-fiction dilemma in autobiography, Stephen A Shapiro says that the genre is somewhat caught in Heisenberg's indeterminacy principle since all novels draw some aspects from the experience of the author's life and similarly all autobiographies are subject to the 'distorting' principle of art and "there is no possibility of separating a phenomenon from the devices used to measure it" (2007, p.109). Georg Misch, following the same line of thought, points out the genre's chameleon-like character in which the autobiographer exists in the form of 'heterobiographer'. Jean Starobinski, while reflecting on the wide variety of styles that each autobiography follows, writes that "it is essential to avoid speaking of an autobiographical-"style" or even an autobiographical "form" because there is no generic style or form" (1971, pp.285-94). The theorist Georges Gusdorf as much asserts the heroics of autobiography as he underlines the non-finalizability as its essential tenets. New terminologies to address diverse self-referential writings within the field have been coined, e.g. 'self-biography' by Felicity Nussbaum, 'autography' by H. Porter Abbott, 'autogynography' by Domna C.Stanton, 'otobiographie' by Jacque Derrida and so on. Autobiography's much terminological variation as well as its inconsistent style and form renders the narrative of the self undecidable. In other words, a definitional unease looms large in autobiography in the present time when the very concept of the Western masculinist Enlightenment self is subject to decentering. Linda Anderson suggests that " in so far as autobiography has been seen as promoting a view of the subject as universal, it has also underpinned the centrality of masculine - and we may add, Western and middle class - modes of subjectivity" (2007, p. 3). The postcolonial writers and theorists attempt to rescue autobiography 
from such dominant ethnocentric and paternalistic modes of life-writing. Sidonie Smith and Julia Watson also express that the term autobiography is "inadequate to describe the extensive historical range and the diverse genres and practices of life narratives and life narrators in the West and elsewhere around the globe" (2001, p.4). The decentering of the subject or the critique of the sovereign self which is closely coupled with the issue of author and authorship in the poststructuralist era brings forth a de-defining moment in autobiography when autobiography turns against itself.

\section{Autobiography as Life-writing: The Postcolonial Experiment}

The journey of autobiography as a genre in the history of the West has always been underlined with transitions. From its shift from the thematic of religious to the secular, from its focus of great men to ordinary lives, from a field primarily monopolised by men to a practice by women, from a rigid genre to an inclusive one, from being originated in the West to a much written subject in the post colonies, autobiography has witnessed a great transition in terms of time and scope. However, one might point to an internal shift within the process of writing the self, i.e. the shift from writing the ontology of the autos to writing about or around the self, reflecting the empirical dimensions of life. Postcolonial autobiography is mostly a mode of resistance writing. The socalled resistances to autobiography are articulated to underline the postcolonial ambivalence in terms of identities and liminality of locations. If a unified account of the self is not available or possible, the autobiographer has turned their life-writing for strategic purposes. Edward Said was eloquent about such resistance to autobiography in a conversation with Jacqueline Rose about his autobiography Out of Place: "It is not really an autobiography. I've resisted the use of that word. I call it a memoir, because, first of all I'm not really a public figure [...]. But I feel that I had something to understand about a peculiar past" (Huddart, 2008, p.45). Said's claim is suggestive of his fragmentary existence, dislocated historical reality that he is part of and also of the identity politics inherited by him. The fragmentary existence conveyed in Out of Place through the details of the pronominal shifts bearing the Palestinian sense of foreignness within, Said's text creates a confusion between multiple subject positions. The complicated historical inheritance from Palestine intertwined with the personal self 'inventions' is manifest in Said's After the Last Sky in which he elaborates his growing unease with the historical and contemporary political forces. A similar form of withdrawal from autobiographical closure can be seen in Helene Cixous' Stigmata, or Job the Dog. "It is an autobiographical narrative which does not mean very much, because autobiographical narrative is at the same time a creation" (Cixous, 1998, p.183). Such an opinion questions autobiography as the bearer of authentic details about the self and presents multitudinous complexities involved in the writing of autobiography. It is important to mention that the resistance to autobiography is, however, a deliberate reinstatement of the autobiographical self. In fact, resistance to autobiography and deconstruction of the genre in postcolonial milieu becomes a strategy to overthrow the centrality of the white western male agency and incorporate the marginal voices.

Julia Watson and Sidonie Smith argue that the marginalised subject assumes centrality in the discourse by taking recourse to autobiographical practices that go against the grain and constitutes a space from where it can engage with creativity as well as intervene in the politics. The subjectivity of the postcolonial subject as centred yet decentred becomes quite ambivalent. Frantz Fanon writing about this ambivalent postcolonial subjectivity in Black Skin, White Masks 
comments that self-reconstitution by writing the self becomes a strategy to resist the psychic disintegration that brought onto the colonial subject. The subject is fractured into 'a triple person' by the onslaught of racial treatment. Although Fanon attempts to recover the parts and conjoin them with the whole; he on a contrary note points out that there is no single whole by which Negro experience can be summarised, for "Negro experience is not a whole, for there is not merely one Negro, there are Negroes" (Fanon, 1986, p.136). The postcolonial life-writing marks a departure from the Western form in its ambivalent presentation of subjectivity. Bart Moore Gilbert further comments that "whether figured as 'weaving' (Morgan), 'chequering' (Equiano) or 'striping' (Fanon), the postcolonial identity rarely seeks to utterly disavow the effects of colonialism on its constitution" (2009, p.15). It is to be underlined that life-writings from the postcolonial space are beset with many contradictions and complexities. Such writings are underscored by a crisis in the self and the society and the narratives are products of the collaboration with others, which can include society, place, milieu and the given temporality all subsumed under a singular yet plural self.

In Selves in Question: Interviews on South African Auto/biographies, J M Coetzee expresses that in spite of the singular narrative identity created by the author over a period of time, autobiography - an account of the self is always in a significant way an autrebiography - an account of the other. An autobiography may be signed by a single person as the author but it tells the story of many others, hence the product becomes collaborative and mediated. The singularity of a written life therefore remains impossible in absence of the stories of other lives. Postcolonial autobiography willy-nilly becomes a dialogical and collective production. The collaborative autobiographies or the 'mediated testimonies' provide a sense of collective identities and a dialogical mode of understanding of self. The individual identities, in a large number of autobiographies in South Africa, written during the Apartheid period and during the struggle and reconciliation become part of a collective identity and the autobiographies turn into a community narrative, complicating the discourse of life-writing while enriching understanding of the self/identity.

Postcolonial life-writing is marked by the trait of decentredness; the colonized body bears signs of fragmentation to such an effect that it longs to recover its earlier unified existence. The process of identity formation in respect of women in the postcolonial life-writings is always much complicated as they negotiate with dual forces of colonialism and patriarchy with the space of self-narration being almost denied to them. Assia Djebar's Fantasia: An Algerian Cavalcade (1985) is a complex articulation of the historiography in colonial Algeria where Djebar mentions the necessary veil or the garb of anonymity that women must wear in autobiographical enterprise. Djebar writes that even well-educated privileged women have to conform to 'two absolute rules' of never talking about oneself, and self-narration, if at all, must happen anonymously. Such a rule no doubt goes against the principle of autobiography and challenges the Western notion of autobiography as the story of sovereign selfhood; nonetheless Djebar builds up her identity through anonymity, presenting the Algerian woman as a collective entity and their relation to modern Algerian nation. Djebar's is a classic case that deliberates on the predicament of women who always live under veil or anonymity and how their participation in the anti-colonial struggle is relegated to margin in Algeria under political, religious and patriarchal traditions. Djebar's idea of fantasia remains "directly linked to the project of cultural decolonisation" (Gilbert, 2009, p.100). 
Thus the life story becomes a struggle between loss and recovery wherein both possibilities hinge upon in retrieving collective memory of the past and articulating collective suffering of the present. Sally Morgan's My Place is such an example of postcolonial life-writing of an aboriginal Australian trying to construct a new integrated identity from a fractured past inflicted by colonialism. Morgan's autobiography de-centres her autobiographical self in its attempt to accommodate other voices in the family, thereby making it a collective autobiography. In Meatless Days: A Memoir (1989) Suleri's complex self-portraiture is subsumed under her detailed accounts of family biography, the indigenous tradition, and the history of the Pakistani nation at large. It has been customary for the postcolonial life-writers to present themselves as representatives of the community; in other words, autobiography becomes a collective activity. In Suleri's autobiography, linear development of her singular self is missing, the individual and the collective accounts concurrently travel as the narrative is "'evenly distributed' between Suleri herself, family members and the seemingly inexorable degeneration of the new nation" (Gilbert, 2009, p.103). The postcolonial life-writings indigenise the narrative while constructing the subjectivity vis-à-vis the collectivity, flouting the norms of traditional Western autobiography. The decentring of self under colonialism manifests in Olaudah Equiano's autobiography The Interesting Narrative. It posits itself as a representative African life narrative depicting the disjunctive subjectivity, but the hybrid ethnic identity of the protagonist denies assimilation with the dominant British, as he experiences continuous discrimination by the English tradition. The fracture and dislocation of the colonized self is reflected in the narrative's centrifugal tendencies.

Postcolonial life-writing although follows the Western autobiographical narrative mode, constantly challenges the very process of writing itself. Instead of being considered as a selfauthenticated narrative, it is haunted by many other voices that have been silenced under colonialism. The generic purity of autobiography thereby is questioned. For Derrida, the word genre is couched in certain prescriptive rules and norms; hence the law of the genre is the 'law of purity, a law against miscegenation' (Frow, 1995, p. 26). According to Derrida, "as soon as genre announces itself, one must respect a norm, one must not cross a line of demarcation, one must not risk impurity, anomaly or monstrosity" (Derrida, 1980, pp. 203-204). He argues that a text circumscribed by a genre announces itself as a poem, drama or a novel, but the textual markers like title and signature do not fall into the purview of the given genre. The basic point of Derrida's argument is that no text fully conforms to the 'norms and interdiction' of any particular genre. Theorised from this angle, autobiography exemplifies the Derridean "law of genre" par excellence. The 'law of genre' is based on the "law of impurity or a principle of contamination" (Derrida, 1980, p.225), as Derrida further contends:

Every text participates in one or several genres, there is no genre less text; there is always a genre and genres, yet such participation never amounts to belonging. And not because of an abundant overflowing or a free, anarchic and unclassifiable productivity, but because of the trait of participation itself, because of the effect of the code and the generic mark (1980, p.230).

In Derridean parlance autobiography participates in several genres or gets co-opted by other genres underlining its intertextuality. As a particular genre crosses its boundary and incorporates another, the process is mediated through its relationship with other discourses. The Derridean passage from auto to oto as well as the shift from one genre to the other is marked by the 
discourse of the other whether it is the self or the genre as an abstract body of knowledge that accommodates the other. While addressing the border line between the work and life, it is also necessary to look at the porous genre borders. The autobiographical texts straddle the borders between fiction and autobiography, memory and history, ethnography and history and so on. By transgressing generic borders and accommodating the other within, autobiography establishes itself as an intertext. Ann Jefferson in her essay "Autobiography as Intertext" addresses such generic complexity inherent in fiction and autobiography:

To presuppose that there are generic distinctions between novels and autobiographies, even while the fiction is being revealed as autobiographical and the autobiographies as fictional, since in this sphere (if not in all others) generic differences need to be respected as an effect of reading, even if they cannot be defined as intrinsic qualities of the texts in question. (1990, p.109).

Life-writing as such is discursive and more so in the context of postcolonial practice of the genre. In the postcolonial context, autobiography is marked by generic hybridity as the subject traverses history through colonial encounter. Referring to the haunting presence of the autobiographical, Gayatri C Spivak contends that the postcolonial writers conceive their narratives as 'withheld autobiography' in her discussion of Assia Djebar's novel Fantasia (1998, p.10). The Autobiography of My Mother (1996) by the Caribbean writer Jamaica Kincaid announces itself as an autobiography, but it is classified as a novel in the cover of the book. Leigh Gilmore identifies Kincaid as a 'hybrid-autobiographer' recalling her successive fictions, which are apparently autobiographical, crossing the boundaries of both conventional autobiographical first person narrative and the fictional text. V S Naipaul's writings criss-cross genres troubling the borderlines between fiction, autobiography, and travel-narrative, which become symptomatic of overlapping identities and fractured subjectivities. Naipaul marks his foreword to Finding the Centre as "Prologue to Autobiography" although he emphasizes that it is "not an autobiography, [but] a story of a life or deeds done", while referring it to a 'personal narrative' (Naipaul, 1984, p. 9). Thus a refusal to situate himself as an autobiographical subject occurs because of a cultural gap that afflicts the Caribbean subjects. In Caribbean Autobiography: Cultural Identity and SelfRepresentation (2002), Sandra Pouchet Paquet analyses how dominant Anglo-Caribbean autobiographies by Claude McKay, Derek Walcott, George Lamming, V S Naipaul, Jean Rhys, Jamaica Kincaid, Kamau Brathwaite and others construct a distinct Caribbean identity despite the inherent tensions and contradictions of a heterogeneous community. The autobiographies range from slave narrative to travel narrative, narratives of childhood, autobiographical fiction, and narrative poem, and are diverse in form, function and narrative modes, which make inter-generic negotiation an important component of autobiographical discourse. The inter-generic interaction, which becomes a distinctive mark of the autobiographies in the process of decolonisation, reiterates that autobiography as a genre resists any singular or unified 'sovereign' self by accommodating the other in both structural and literal sense. By so doing, life-writing in contemporary time marks a departure from Gusdorf's argument that autobiography in the nonWest is inherently derivative of the Western counterparts.

\section{Life-writing: The Indian Experience}


The concern with life-writing, although much conspicuous in decolonization, however, is not limited to the political perception of the process. Life-writing as a genre in the Indian subcontinent has been experimented in diverse ways - be it political, religious, celebratory and ordinary - lives have been narrated with different viewpoints and objectives. Life-writing has emerged as a popular genre in recent period as the traditional idea of writing the self, unlike Gusdorf's opinion, is not restricted to lives of the 'great' men or more specifically to the 'white male subject'. Since the nineteenth century, the upsurge of life-writing across the Indian society has been such that a diverse representation of the self in different contexts and locations build up life-histories that underline a constant negotiation of the individual identity with the collective and national identity. The varied life-writings criss-crossing diverse disciplinary domains have created a unique sense of life-writing that reflects the society at large. Commenting on the overwhelming presence of 'public' in private selves in the nineteenth century novels, diary, letters and autobiographies in India, Dipesh Chakrabarty writes, "they seldom yield pictures of an endlessly interiorized subject. Our autobiographies are remarkably "public" (with construction of public life that are not necessarily modern) when written by men and tell the story of the extended family when written by women" (Chakrabarty, 2001, p.35).

Chakrabarty's statement is germane to the theory of autobiography as a narrative beyond a singular life and also to the self-making practice in the colonised nation that can interfere with subject-hood itself. Chakrabarty elaborates his argument with his analysis of N C Chaudhuri's Autobiography of an Unknown Indian where only a passage about Chaudhuri's private life occurs, while the entire narrative is being enveloped by public life. Prafulla Mohanti's My Village, My Life: Portrait of an Indian Village (1973) is such a paradigmatic structure of self- narration par excellence as he sketches a small village in Orissa with the changing life, tradition, and village tales. Correspondingly, the representative autobiographies in the decolonising era such as by Gandhi and Nehru constantly negotiate with the larger force of history and nation; invocation of both being a co-presence in the postcolonial writing in general. The dispersal of life's narrative across the oeuvre of a writer is what makes autobiography inconclusive and ongoing. R K Narayan's memoir My Days raises such an issue of non-finalizibility of the life's narrative in the form of autobiography: "How can an autobiography have a final chapter? At best it can only be a penultimate one; nor can it be given a rounded-off conclusion, as is possible in a work of fiction" (1974, p.185).

It can be argued that although colonialism was the most conducive condition to life-writing in India to flourish, other social conditions such as patriarchy and caste system were equally important to produce life-writings by women and dalits who had to move through the complex negotiation of female/dalit/marginalised subjectivities. One of the earliest autobiographies to emerge in India is Amar Jiban (My Life) by Rashsundari Devi (1809-1899), an upper class rural Bengali housewife, who uses life-writing as the medium of the self's negotiation with much denied and distanced public sphere in her portrayal of the life of women in Bengal of her time almost spanning over a century. The domestic sphere as the defining world of women runs through the text with the insistent motif of the caged bird. Rashsundari simultaneously occupies two diverse spheres - a conformist housewife in a Hindu orthodox family and a writer in the public life, atypical to women of her time. Binodini Dasi's autobiography Amar Katha (The Story of My Life) published in 1913 is an account of her life as a lowly born prostitute turned courtesan who becomes an 
actress in popular drama in the nineteenth century Bengali theatre. Although she is liberated from the upper-class inhibitions, she is alienated from the society at large for not conforming to the established codes of femininity. However, autobiographies by women in the subsequent period e.g. Sudha Majumadar's Memoirs of an Indian Woman (1989), Laxmibai Tilak's I Follow After (1934-37), Manikuntala Sen's In Search of Freedom, Sarala Devi Chaudhurani's memoirs Jiboner Jhara Pata (Life's Fallen Leaves) interrogate patriarchy and counter the culture and gender politics of the time and also supplement the grand narrative of emerging national consciousness. However, self-narration by women in a conservative society was very challenging. The autobiographical writings of Mahadevi Verma conceal her private self and distance her writerly self from her real self by employing various writing strategies. The 'female self' in these autobiographies is not a stable entity, but is constantly in the process or 'becoming' in its negotiation with 'modernity'. The life-writings by these women capture a distinctively Indian (Hindu) worldview as there is also a synthesis of the Indian tradition along with the voice of protest against patriarchy. Kamala Das's autobiography My Story (1973) is such a fiercely candid account of her self and sexual awakening which interrogates the hypocrisies of a traditional Indian society with patriarchy as the dominant force. The contemporary women's life-writings bring out the duality between female subjectivity and identity as a construct and the actual lived life of women. More recently one sees the proliferation of life-writing as one reads lives from the periphery of the society written in Indian vernaculars and subsequently translated into English. The accounts like $A$ Life Less Ordinary by Baby Halder, tell the brave story of a domestic worker who amidst all odds makes her ways to writing and establishes herself as a writer. What is important here is the act of writing that can give agency to the otherwise marginal lowly self and also encompass the class history. As Urvashi Butalia in her foreword to Life Less Ordinary observes, "... Baby's story is not unique. It is the story of thousands of women caught in similar situations across the world..." (Halder, 2013, p.viii), but what makes her story different is her absolute commitment to education, her desire to read and write. Nalini Jameela's account The Autobiography of a Sex Worker, and A Revathi's The Truth About Me: A Hijra Story are attempts to establish the agency of a sex worker and a third gender in public through writing, delineating the oppression of the sex-workers and transgenders with their recognition in the society as the abhorrent Other. Jameela's autobiography jettisons the dominant womanhood by writing the untold stories of the labouring woman subject at the fringes of the society. It rejects the stereotyped image of the sex-workers by bringing out the tension between her domestic sphere as a woman and mother, and as a sex-worker in 'public life'. A Revathi's The Truth About me unfolds the unflinching truths about the marginalised individual like her who was born a male but wanted to live a life like a woman, the constant unease of being born into a 'wrong' body and the tremendous sense of ignominy suffered in the society as she listens to her inner being and decides to join the transgender community. At once they are individual self-experiences as they are also evocative of a shared narrative, as their destinies mirror the collective. In a different sense, the individual life account becomes a collaborative project through translation and interpretation as can be seen in the life narrative of Phoolan Devi's I, Phoolan Devi: The Autobiography of India's Bandit Queen, a transcribed version of her story reproduced from oral presentation in collaboration with Marie-Therese Cuny and Paul Rambai, bearing her transition from an underdog to a queen. In the epilogue of her autobiography Phoolan desperately craves to tell her story which has been much used and abused by the journalists and movie directors. 
Phoolan's predicament is both individual and collective as her individual experience becomes the metonym of injustice and torture perpetrated to women of her community. The narration of lives in the life-writings follows both syntagmatic and paradigmatic structures i.e. the life-writings are as much about the aspects of a particular self as they are parallel telling about the lives and times of others, the society and tradition at large, often the syntagmatic being subsumed by the paradigmatic.

\section{Conclusion}

Both in theory and practice, life-writing in India marks a departure from the Western modes of self-narration and this departure underscores the resistance inherent in the genre as well as the conflict between self-narration and the Indian metaphysics of self. The self in these narrations is not unitary or sovereign as in the Western counterparts, but pulled toward centrifugal forces of colonialism and other matrices. David Arnold and Stuart Blackburn in their introduction to Telling Lives in India: Biography, Autobiography, and Life History (2004) write that "life-histories in India do not necessarily conform to Western conventions and modes of expression (some do, many don't), nor should one expect to find the peculiar forms of individualism that emerged in the West and replicated in India" (Arnold and Blackburn, 2004, p.3). Bhikhu Parekh observes that, like Hindu metaphysics, limiting the self to certain prescribed roles with little value on individuality defines Hindu social structure that is reliant on plurality and diversity rather than individuality. He further argues that the Hindu epistemology has no place for historical truth given the impermanence of human agency as only moral truth can guarantee universality, though a uniform Hindu epistemology can be much debated. Nonetheless, such dominant worldview was responsible for producing life narratives of saints and religious figures with didactic overtone, with disregard to the details of individual life, moods, feelings, as these were considered unworthy to be written about. A paradigmatic shift in this worldview can be discerned in the recent times with the growing preoccupation with self-narration that signals a new turn to life-writing in the Indian subcontinent when the economically and socially marginalised, deprived and ordinary selves or 'vulnerable subjects' have used life-writing as a potent instrument to retrieve the sense of self and assert their subjectivities with a critical reflection on the dominant practices in the society.

\section{References}

Anand, M.R. (1985). Autobiography, Part One: The Story of a Childhood under the Raj: Pilpali Sahab. Arnold-Heinemann.

Anderson, L. (2007). Autobiography. Routledge.

Anzaldua, G. (2012). Borderlands/La Frontera: The New Mestiza. Aunt Lute Books.

Arnold, D \& Blackburn, S (Eds.). (2004). Telling Lives in India: Biography, Autobiography, and Life History. Permanent Black.

Briggs, C. L. \& Bauman, R. (1992). Genre, Intertextuality, and Social Power. Journal of Linguistic Anthropology. 2(2), 137-72. 
Butalia, U. (2006). Foreword. In Baby Halder, Life Less Ordinary. Zubaan.

Chakrabarty, D (2001). Provincializing Europe: Postcolonial Thought and Historical Difference. Oxford University Press.

Chaudhurani, S. D. (1982). Jibaner Jharapata (Fallen Leaves of Life). Rupa \&Co.

Chaudhuri, N. (1951). The Autobiography of an Unknown Indian. Picador.

Cixous, H \& Calle. G. M. (1997). Rootprints. Memory and Life Writing. (Trans. E. Prenowitz). Routledge.

Cixous, H.(1998). Stigmata: Escaping Texts. Routledge.

Coullie, L. J, et. al. (Eds.).(2006). Selves in Question: Interviews on South African Autobiography. University of Hawaii Press.

Das, K. (2009). My Story. Harper Collins.

Dasi, B. (1912). Amar Katha (My Story). Great Eden Press.

Derrida, J. (1980). Law of Genre. (Trans. A. Ronell). Critical Enquiry. 7(1), 55-81.

Devi, P. (1996). I, Phoolan Devi. The Autobiography of India's Bandit Queen. Little Brown \& Company.

Devi, R. (1999). Amar Jiban. (Trans. Tanika S.). Words to Win: The Making of a Modern Autobiography. Zubaan.

Djbar, A. (1985). Fantasia: An Algerian Cavalcade. (Trans. \& Intro. Dorothy S.B).

Heinemann.

Equiano, O. (1789). An Interesting Narrative and Other Writings. (Ed. Vincent C.). Penguin.

Fanon, F. (1952). Black Skin, White Masks. (Trans. C. L. Markmann). Pluto.

Folkenflik, R. (1993). The Institution of Autobiography. The Culture of Autobiography: Construction of Self Representation. (Ed. Robert F). Stanford University Press,

Frow, J. (2005). Genre. Routledge.

Gandhi, M.K. (1927-29). An Autobiography or The Story of My Experiments With Truth. (Trans. Mahadev D \& Intro. Sunil K). Penguin. Published in 2001. . (1928). Satyagraha in South Africa. (Trans. Valji G. D). Navajivan Publishing House.

Gilbert, B.M.(2009). Postcolonial Life-Writing: Culture, Politics and Self-Representation. Routledge.

Gusdorf, G. (1980). Conditions and Limits of Autobiography. Autobiography: Essays Theoretical and Critical. (Ed.\& Trans. James O). Princeton University Press.

Halder, B. (2006). A Life Less Ordinary. (Trans. Urvashi B). Zubaan.

Huddart, D. (2008). The Postcolonial Theory and Autobiography. Routledge.

Kincaid, J. (1996). Autobiography of my Mother. Farrar Straus.

Jameela, N. (2007). The Autobiography of a Sex Worker. (Trans. with a foreword by J Devika). Westland Ltd.

Jefferson, A.(1990). Autobiography as Intertexts: Barthes, Sarraute and Robbe-Grillet. Intertextuality: Theories and Practices. (Ed. Michael W \& Judith S). Manchester University Press. 
11| Heinemann.

Lejeune, P. (1989). The Autobiographical Pact. On Autobiography. (Ed. Philippe L, with a foreword by Paul J.E, Trans. Katherine L).University of Minnesota Press. (1989). The Autobiography of Those Who Do Not Write. On Autobiography. (Ed. Paul J.E, Trans. Katherine L). University of Minnesota Press.

Majumdar, S. (1999). Memoirs of an Indian Woman. (Ed. Geraldine F). M.E Sharpe.

Mish, G. (1950). Conception and Origin of Autobiography. A History of Autobiography in Antiquity. (Trans. E.W Dickes). Routledege and Kegan Paul.

Mohanty, P.(1973). My Village, My Life: Nanpur Portrait of an Indian Village. Davis-Poynter.

Morgan, S.(1987). My Place. Virago.

Naipaul, V S. (1984). Finding a Centre: Two Narratives. Penguin.

Narayan, R K.(1974). My Days. Viking.

Nehru, J.(1936). An Autobiography. Penguin. (1946). The Discovery of India. Penguin.

Parekh, B. (2006). Indianization of Autobiography. Debating Gandhi. (Ed.A Raghuramaraju). Oxford University Press.

Pauquet, S.P. (2002). Carribean Autobiography. Cultural Identity and Self-Representation. University of Wisconsin Press.

Revathi, A. (2010). The Truth About Me: A Hijra Story. (Trans. V Geetha). Penguin Books.

Said, E. (1999). Out of Place. Granta. (1999). After the Last Sky. Columbia University Press.

Sen, M. (2001) In Search of Freedom: An Unfinished Journey. (Trans from Bengali by Stree, with a foreword by Tapan R). Stree.

Shapiro, A.S. (2007). The Dark Continent of Literature: Autobiography. Autobiography: Critical Concepts in Literary and Cultural Studies. Vol. I. (Ed. Trev L.B.). Routledge.

Shumaker, W. (1954). English Autobiography. California University Press.

Smith, S. \& Watson, J. (2011). Autobiography: A Guide for Interpreting Life Narratives.

University of Minnesota Press.

Specks, P.M. (1977). Stages of Self: Notes on Autobiography and the Life Cycle. Boston University Journal. 25. pp7-17.

Starobinski, J. (2007). The Style of Autobiography. Autobiography: Critical Concepts in Literary and Cultural Studies. Vol. I. (Ed. Trev L.B). Routledge.

Suleri, S. (1989) Meatless Days: A Memoir. Flamingo.

Tilak, L. (1998). I Follow After. (Trans. Josephine I). Oxford University Press.

Watson, J. (1993). Toward an Anti-Metaphysics of Autobiography. The Culture of Autobiography: Construction of Self Representation. (Ed. Robert. F). Stanford University Press. 
12 Rupkatha Journal, Vol. 13, No. 3, 2021 